\author{
Katarzyna Osiak-Krynicka \\ Uniwersytet Marii Curie-Skłodowskiej w Lublinie \\ katarzynaosiak@vp.pl
}

\title{
Rola biegłego psychologa w przesłuchaniu dziecka w trybie art. 185a Kodeksu Postępowania Karnego
}

\author{
The role of an expert psychologist in interrogating a child in the \\ mode of art. 185a of the Code of Criminal Procedure
}

\section{STRESZCZENIE}

W Polsce żyje około 6 milionów dzieci. Niestety, jak wynika ze statystyk rocznie ofiarom przestępstw pada około 10 tysięcy małoletnich. Są to jedynie dane szacunkowe ponieważ nigdy nie dowiemy się ile dzieci rzeczywiście stało się ofiarami przestępstw, ponieważ bardzo często fakt popełnienia przestępstwa nie zostaje zgłaszany na Policję czy prokuraturę. Jeżeli zostanie wszczęte postępowanie karne przeciwko sprawcy krzywdzenia małoletniego, wówczas konieczny może stać się jego udział w procesie, a tym samym jego przesłuchanie w charakterze świadka. W art. 185a Kodeksu postępowania karnego został uregulowany szczególny tryb przesłuchania małoletniego pokrzywdzonego, mający chronić go przed wtórną wiktymizacją. Przesłuchanie odbywa się na posiedzeniu sądu, w którym uczestniczy również biegły psycholog. Celem artykułu jest przedstawienie roli jaką pełni biegły psycholog w przesłuchaniu małoletniego pokrzywdzonego.

Słowa kluczowe: przesłuchanie, biegły, psycholog, małoletni, dziecko

Z nastrojów panujących w polskim społeczeństwie wynika, że jego członkowie wyraźnie sprzeciwiają się popełnianiu przestępstw. Jednakże, mimo organizowania wielu kampanii społecznych przez organizacje pozarządowe, jak np. Fundacja Dajemy Dzieciom Siłę ${ }^{1}$, corocznie około 10 tysięcy dzieci pada ofiarom

1 Fundacja Dajemy Dzieciom Siłę (dawniej Fundacja Dzieci Niczyje) działa od 1991r. Celem tej organizacji jest ochrona dzieci przed krzywdzeniem i pomoc tym, które doświadczyły przemocy oraz by poznały swoje prawa. Fundacja oferuje krzywdzonym dzieciom i ich opiekunom pomoc psychologiczną i prawną, naukę jak uniknąć przemocy i wykorzystywania, oraz informacje dla rodziców jak reagować, gdy podejrzewają, że ich dziecku dzieje się krzywda. Przykładem kampanii 
krzywdzenia ${ }^{2}$. Z przykrością należy podkreślić, iż są to jedynie dane szacunkowe, gdyż do organów ścigania nie są zgłaszane wszystkie przestępstwa wobec dzieci. Przyczyn tego zjawiska należy upatrywać zarówno w samych pokrzywdzonych, czyli dzieciach, które nie wiedzą, że doświadczają przestępstwa (np. nie wiedzą, że molestowanie seksualne jest czymś złym i dopiero w kiedy dorosną zaczynają rozumieć, że to czego doświadczyły było przestępstwem), jak i rodzicach tych dzieci, który nie wierzą im i twierdzą, że naoglądały się zbyt wielu filmów. Ponadto przyczyną niezgłaszania przestępstw wobec dzieci jest również fakt, że są one zastraszane przez sprawców, którzy grożą, skrzywdzeniem ich rodziców, jeżeli powiedzą komukolwiek o tym co się wydarzyło ${ }^{3}$.

Żaden człowiek nie zasługuje na krzywdzenie, a zwłaszcza dziecko - istota, która znajduje się w stanie silnego rozwoju. Jakiekolwiek przejawy krzywdzenia wobec dzieci, o których informują media spotykają się ze sprzeciwem polskiego społeczeństwa. Jeżeli jednak, na Policję lub prokuraturę zostanie złożone zawiadomienie o popełnieniu przestępstwa na szkodę dziecka, konieczny może się stać jego udział w postępowaniu karnym. Dla osoby dorosłej, doświadczenie przestępstwa wiąże się z silnym stresem i cierpieniem. U osoby małoletniej te uczucia są spotęgowane, co wynika z faktu, że znajduje się ona na etapie silnego rozwoju emocjonalnego i psychicznego. Ponadto doświadczenie przez dziecko bardzo ciężkiego przestępstwa jak m.in. przemoc domowa czy wykorzystywanie seksualne może doprowadzić do zaburzeń jego rozwoju i spowodować negatywne konsekwencje w dorosłym życiu. Wobec tego, ustawodawca wprowadził wiele instytucji, które mają na celu zagwarantowanie ochrony dziecku, które uczestniczy w postępowaniu karnym, przed pogłębieniem krzywdy i cierpienia, które może być spowodowane nieumiejętnym postępowaniem z pokrzywdzonym dzieckiem mającym np. składać zeznania w charakterze świadka.

Jedną z form ochrony dziecka w procesie karnym jest specjalny tryb przesłuchania uregulowany w art. 185a Kodeksu Postępowania Karnego ${ }^{4}$. Obecnie obowiązująca treść art. 185a KPK została wprowadzona ustawą nowelizującą z dnia 13 czerwca 2013r., która weszła w życie w dniu 27 stycznia 2014r. Zgodnie z treścią

społecznej organizowanej przez Fundację Dajemy Dzieciom Siłę, a mającą na celu przeciwdziałanie krzywdzeniu dzieci jest np. Program przeciwdziałania komercyjnemu wykorzystywaniu dzieci.

2 Dzieci-ofiary przestępstw seksualnych, dostęp: http://www.statystyka.policja.pl/st/informacje/50010,Dzieci-ofiary-przestepstw-seksualnych.html.

3 Gadomska-Radel A., Przestuchanie dziecka jako ofiary przestępstwa, Warszawa 2015, s. 120; Zmarzlik J., Przygotowanie dziecka do uczestnictwa w przestuchaniu [w:] Sajkowska M.( red.), Przyjazne przesłuchanie dziecka, FDN, Warszawa 2007; Budzyńska A., Diagnoza psychologiczna wykorzystywania seksualnego dzieci [w:] Sajkowska M.( red.), Dziecko wykorzystywane seksualnie. Diagnoza, interwencja, pomoc psychologiczna, FDN, Warszawa 2010.

4 Ustawa z dnia 6 czerwca 1997r. - Kodeks Postępowania Karnego (Dz. U. z 2018 r. poz. 1987, 2399). 
tego przepisu, w sprawach o przestępstwa popełnione z użyciem przemocy lub groźby bezprawnej lub określone w rozdziałach XXIII (przestępstwa przeciwko wolności), XXV (przestępstwa przeciwko wolności seksualnej i obyczajności) i XXVI (przestępstwa przeciwko rodzinie i opiece) Kodeksu karnego ${ }^{5}$, w tym specjalnym trybie można przesłuchać pokrzywdzonego, który w chwili przesłuchania nie ukończył 15 lat oraz małoletniego, który w chwili przesłuchania ukończył 15 lat, jeżeli zachodzi uzasadniona obawa, że przesłuchanie w innych warunkach mogłoby wywrzeć negatywny wpływ na jego stan psychiczny. Małoletniego można przesłuchać tylko wówczas, gdy jego zeznania mogą mieć istotne znaczenie dla rozstrzygnięcia sprawy, i tylko raz, chyba że wyjdą na jaw istotne okoliczności, których wyjaśnienie wymaga ponownego przesłuchania lub żąda tego oskarżony, który nie miał obrońcy w czasie pierwszego przesłuchania pokrzywdzonego.

Przesłuchanie odbywa się na posiedzeniu sądu w Przyjaznym Pokoju Przesłuchań, na który składają się: pokój przesłuchań, w którym faktycznie odbywa się przesłuchanie, pokój techniczny oraz poczekalnia ${ }^{6}$. Zgodnie z $§ 6$ Rozporządzenia Ministra Sprawiedliwości z dnia 18 grudnia 2013r. w sprawie sposobu przygotowania przesłuchania przeprowadzonego $\mathrm{w}$ trybie określonym $\mathrm{w}$ art. $185 \mathrm{a}-185 \mathrm{c}$ Kodeksu postępowania karnego, pokój przesłuchań może znajdować się w siedzibie sądu, prokuratury, Policji, instytucji państwowej lub samorządowej albo podmiotu, do zadań którego należy pomoc małoletnim lub ofiarom przestępstwa zgwałcenia.

Artykuł 185a KPK przewiduje ograniczoną liczbę osób uczestniczących w tym trybie przesłuchania, gdyż większa liczba mogłaby spowodować zakłócenie koncentracji uwagi oraz ograniczać zaufanie i gotowość do współdziałania ${ }^{7}$. Zgodnie $\mathrm{z}$ treścią art. 185a KPK w przesłuchaniu biorą udział: sąd, biegły psycholog, prokurator, obrońca, pełnomocnik pokrzywdzonego oraz przedstawiciel ustawowy małoletniego lub osoba pełnoletnia wskazana przez pokrzywdzonego. Wspomniany katalog osób można podzielić na dwie grupy: osoby, które biorą udział przesłuchaniu oraz osoby, które są podczas przesłuchania obecne, przysłuchując się mu w pokoju technicznym. Do pierwszej grupy należy zaliczyć: sędziego, który przesłuchuje dziecko oraz biegłego sądowego, który aktywnie uczestniczy w tej czynności, pomagając sędziemu (formy pomocy biegłego psychologa zostały opisane niżej). Natomiast, do drugiej grupy należy zaliczyć: prokuratora, obrońcę, pełnomocnika pokrzywdzonego, przedstawiciela ustawowego oraz osobę pełnoletnią wskazaną przez pokrzywdzonego ${ }^{8}$.

5 Ustawa z dnia 6 czerwca 1997r. - Kodeks karny (Dz. U. z 2018 r. poz. 1600, 2077).

6 K. Osiak, Kryminalistyczno-procesowe aspekty przestuchania w trybie art. 185 a k.p.k., «Prokuratura i Prawo», 2018, nr 6 s. 137-156.

7 J. Mierzwińska-Lorencka, Karnoprawna ochrona dziecka przed wykorzystywaniem seksualnym, dostęp el/LEX, dostęp na dzień: 25 stycznia 2019 r.

8 Wyrok Sądu Apelacyjnego z dnia 21 września 2004 roku, sygn. akt II Aka 135/04, LEGALIS nr 72679. 
Zgodnie z treścią art. 185a KPK przesłuchanie małoletniego pokrzywdzonego przeprowadza sąd. Do czasu wprowadzenia powyższej regulacji do Kodeksu postępowania karnego istniał spór, kto powinien przesłuchiwać małoletniego pokrzywdzonego - sąd czy biegły psycholog ${ }^{9}$. Znawcy psychiki dziecięcej przedstawiali argumenty przeciwko udziałowi organów wymiaru sprawiedliwości w przesłuchaniu małoletniego pokrzywdzonego. Natomiast przedstawiciele wymiaru sprawiedliwości opowiadali się za tym, aby przesłuchanie było przeprowadzane przez funkcjonariuszy Policji, prokuratorów lub sędziów z pominięciem jakiejkolwiek roli biegłego psychologa $\mathrm{w}$ tej czynności ${ }^{10}$. Ostatecznie został wypracowany złoty środek, który znalazł odzwierciedlenie w treści przepisów Kodeksu Postępowania Karnego, a dokładniej w art. 185a § 2 KPK in principio, zgodnie z treścią, którego przesłuchanie przeprowadza sąd na posiedzeniu z udziałem biegłego psychologa. Jednakże, mimo istnienia regulacji określającej rolę sądu i biegłego psychologa podczas przesłuchania małoletniego pokrzywdzonego ten spór nie został do końca zażegnany i w dalszym ciągu są podnoszone postulaty przez psychologów, aby to właśnie biegłemu psychologowi przypadała większa rola podczas tej czynności ${ }^{11}$. Kodeks postępowania karnego nie określa wprost właściwości rzeczowej sądu do dokonania czynności przesłuchania małoletniego pokrzywdzonego. Jeżeli przesłuchanie dziecka odbędzie się w postępowaniu przygotowawczym to do jego przeprowadzenia właściwy jest sąd powołany do rozpoznania sprawy w pierwszej instancji, czyli sąd rejonowy lub okręgowy, w zależności od tego jakie przestępstwo zostało popełnione na szkodę małoletniego ${ }^{12}$. W postępowaniu sądowym takie przesłuchanie przeprowadza sąd, przed którym toczy się postępowanie, a sąd okręgowy będzie właściwy tylko w sytuacji, gdy na szkodę małoletniego zostało popełnione przestępstwo objęte właściwością rzeczową sądu okręgowego oraz w sytuacji gdy nastąpi zmiana właściwości sądu ze względu na szczególną zawiłość sprawy zgodnie z art. $25 \S 2$ KPK lub łączność podmiotową sprawy, określoną $\mathrm{w}$ art. $33 \S 1 \mathrm{KPK}^{13}$.

Wyżej wskazałam, że osobą, która bierze udział w przesłuchaniu małoletniego w trybie art. 185a KPK, jest biegły psycholog i to właśnie roli tej osoby w przesłuchaniu małoletniego zostaną poświęcone rozważania zawarte w niniejszym artykule.

${ }^{9}$ M. Kornak, Małoletni jako świadek w procesie karnym, Warszawa 2009, s.127.

${ }^{10} \mathrm{M}$. Brojek, Uwagi i postulaty dotyczace taktyki przestuchania w charakterze świadka osoby nieletniej, «Prokuratura i Prawo», 1998, nr 1, s.98.

11 M. Kornak, op. cit., s. 127.

12 R.A. Stefański, Przestuchanie pokrzywdzonego poniżej lat 15 w procesie karnym [w:] Wspótczesne problemy procesu karnego i jego efektywności. Księga pamiątkowa profesora Andrzeja Bulsiewicza, red. A. Marek, Toruń 2004, s. 385.

${ }^{13}$ M. Horna, Nowelizacja kodeksu postępowania karnego a ochrona matoletniego podczas przestuchania, «Dziecko krzywdzone. Teoria, badania, praktyka», vol. 13 Nr 2 (2014), s. 18. 
Biegły psycholog, który uczestniczy w przesłuchaniu małoletniego pokrzywdzonego, jest pomocnikiem i konsultantem sądu podczas tej czynności procesowej. Współuczestniczy on w wykonywaniu przez ten organ czynności, mających bardzo często istotny wpływ na przebieg i rezultat procesu karnego ${ }^{14}$. Biegły wspiera wiedzą specjalistyczną sąd i w pewien sposób daje gwarancję rzetelności i prawdziwości przesłuchania oraz ocenia psychikę i percepcję pokrzywdzonego małoletniego ${ }^{15}$. Jak słusznie stwierdził M. Leśniak: "dla organu procesowego biegły jest, tym czym mikroskop dla biegłego"16. Samodzielną podstawą udziału biegłego psychologa w przesłuchaniu małoletniego jest art. 185a KPK. Z treści tej regulacji wynika, że udział biegłego w tej czynności jest obligatoryjny i niezależny od stanu zdrowia psychicznego pokrzywdzonego, jego zdolności do postrzegania, rozwoju umysłowego czy odtwarzania spostrzeżeń przez niego spostrzeżeń ${ }^{17}$.

Każde dziecko wymaga innego podejścia, zwłaszcza jeżeli doświadczyło traumatycznych przeżyć. Fakt ten uzasadnia udział biegłego psychologa w przesłuchaniu małoletniego. Sędzia, który na co dzień nie pracuje z dziećmi może mieć nie tylko trudności z przeprowadzeniem takiego przesłuchania bez udziału biegłego psychologa, ale również z oceną dowodu z zeznań dziecka, a w konsekwencji, $\mathrm{z}$ ustaleniem prawdy ${ }^{18}$. Wobec czego, do efektywnego przesłuchania dziecka potrzebny jest udział psychologa, który posiada wiedzę specjalistyczną, umiejętności i doświadczenie w pracy z dziećmi. Szczególne trudności mogą pojawić się w sytuacji, gdy przesłuchiwany jest małoletni pokrzywdzony na tle seksualnym. W takim przypadku, psycholog musi w sposób delikatny i dyskretny ustalić wiedzę dziecka na temat życia płciowego oraz szczegółów anatomicznych, funkcji fizjologicznych ludzkiego organizmu i ewentualnie posiadania przez małoletniego informacji o takich czynach jak zgwałcenie ${ }^{19}$.

Biegły psycholog jest powołany do udziału w przesłuchaniu na mocy postanowienia sądu, niezależnie od tego, czy przesłuchanie odbywa się w postępowaniu przygotowawczym czy sądowym. W tym postanowieniu sąd powinien określić zakres ekspertyzy, jej przedmiot oraz wskazać pytania szczegółowe. Do przykładów pytań szczegółowych jakie formułuje sąd należy zaliczyć: czy pokrzywdzony

${ }^{14}$ R. Kosior, Wybrane zagadnienia w zakresie przestuchiwania małoletniego świadka na tle art. 185 a i 185 b kpk, «Dziecko krzywdzone. Teorie, badania, praktyka», 2010, nr 1, s. 20.

15 J. Mierzwińska-Lorencka, Karnoprawna ochrona dziecka przed wykorzystywaniem seksualnym, dostęp el/LEX, dostęp na dzień: 25 stycznia 2019r.

${ }^{16}$ M. Leśniak, Wybrane problemy badań psychologicznych w procesie karnym, «Prokuratura i Prawo», 1998, nr 5, s. 77.

${ }_{17}$ R.A. Stefański, op. cit., s. 389-390.

18 A. Wesołowska, Dziecko w procesie sadowym - podejście interdyscyplinarne, «Dziecko krzywdzone. Teoria, badania, praktyka», vol. $4 \mathrm{nr} 1$, s. 3-4.

19 A. Gadomska, Przygotowanie do przestuchania małoletniej ofiary w charakterze świadka, «Prokuratura i Prawo», 2008, nr 7-8, s. 192; M. Horna, op. cit., s. 24-25. 
wykazuje objawy gwattu lub molestowania seksualnego?, czy można przyjąć, że świadek przeżyt doświadczenia zwiąane z przemoca seksualna?, czy świadek jest prawidłowo rozwinięty intelektualnie?, jakie skutki w psychice pokrzywdzonej obecnie oraz na przyszłość moga powstać na tle przedmiotowej sprawy?, czy można u małoletniej zaobserwować podatność na sugestię lub ukierunkowanie zeznań? ${ }^{20}$ $\mathrm{Z}$ badań aktowych przeprowadzonych przez J. Mierzwińską-Lorencką, wynika, że sądy bardzo lakonicznie formułują postanowienia o powołaniu biegłego i można odnieść wrażenie, że sędziowie wpisują dane personalne w gotowe szablony nie formułując pytań szczegółowych. Co więcej, sędziowie bardzo rzadko precyzowali jakie okoliczności są szczególnie istotne dla ustaleń faktycznych w sprawie i na co powinien zwrócić uwagę psycholog, który ma wziąć udział w przesłuchaniu ${ }^{21}$.

Zgodnie z treścią art. $195 \mathrm{KPK}$, do pełnienia czynności biegłego jest obowiązany nie tylko biegły sądowy, lecz także każda osoba, o której wiadomo, że ma odpowiednią wiedzę $\mathrm{w}$ danej dziedzinie. $Z$ treści tego przepisu wynika, że sąd powołuje biegłego ze specjalnej listy biegłych, prowadzonej przez prezesa sądu okręgowego, jak również może powołać biegłego ad hoc. Mając na uwadze specyfikę przesłuchania w trybie art. 185a KPK, należy zastanowić się czy nie powinna zostać utworzona specjalna lista biegłych psychologów, którzy specjalizują się w pracy z dziećmi, gdyż nie każdy psycholog posiada odpowiednie kwalifikacje do udziału w takiej czynności. Jakie wobec tego, wymagania powinien spełniać biegły psycholog, który ma zostać powołany do udziału przesłuchaniu małoletniego? Powinien on przede wszystkim posiadać odpowiednie kwalifikacje wykazane właściwymi dokumentami o ukończeniu stosownych szkoleń oraz doświadczenie w pracy z dziećmi i łatwość nawiązania z nim kontaktu. Sąd powinien wcześniej zbadać czy dana osoba posiada wiedzę z zakresu psychologii rozwojowej i klinicznej dziecka oraz znajomość technik przesłuchania, np. poprzez zapoznanie się z dokumentami poświadczającymi jego kwalifikacje zawodowe ${ }^{22}$. Mimo, iż sposób weryfikacji kompetencji biegłego nie został uregulowany w prawie, ze względu na specyfikę czynności jaką jest przesłuchanie małoletniego w trybie art. 185a KPK, warto sformułować postulat, aby zanim psycholog zostanie powołany na biegłego, sędzia przeprowadził z nim rozmowę w celu weryfikacji wiedzy na temat tego rodzaju przesłuchania, umiejętności postępowania z dziećmi, unikania pytań złożonych gramatycznie oraz pytań sugerujących, a także czy psycholog posiada cierpliwość, która pozwoli mu na podążanie za aktywnością dziecka. Wobec powyższego należy stwierdzić, iż sędziowie nie powinni wybierać na biegłych psychologów aktualnie dostępnych osób, którzy często nie mają ani

${ }^{20}$ J. Mierzwińska-Lorencka, Karnoprawna ochrona dziecka przed wykorzystywaniem seksualnym, dostęp el/LEX, dostęp na dzień: 25 stycznia 2019r.

${ }_{21}$ J. Mierzwińska-Lorencka, Karnoprawna ochrona dziecka przed wykorzystywaniem seksualnym, dostęp el/LEX, dostęp na dzień: 25 stycznia 2019 r.

22 J. Zmarzlik, op. cit., s.77. 
doświadczenia w pracy z dziećmi, ani nie znają specyfiki przesłuchania, która wskazuje, że posiadanie nawet najpełniejszej wiedzy z zakresu psychologii dziecięcej nie przesądza o byciu dobrym ekspertem ${ }^{23}$.

Rola biegłego psychologa powołanego do udziału w przesłuchaniu małoletniego pokrzywdzonego sprowadza się do trzech czynności: przygotowania małoletniego do udziału w przesłuchaniu, uczestniczenia w faktycznym przesłuchaniu w pokoju przesłuchań oraz wydaniu opinii po odbytym przesłuchaniu. Zanim jednak biegły psycholog przystąpi do przygotowania małoletniego do udziału w przesłuchaniu, musi zapoznać się z materiałem zgromadzonym w sprawie, $\mathrm{w}$ takim zakresie, aby poznać sytuację małoletniego.

Przygotowanie małoletniego do udziału w przesłuchaniu jest prawem przesłuchiwanego dziecka ${ }^{24}$. Jednakże to uprawnienie nie zostało uregulowane ustawowo. Jak wynika z praktyki organów wymiaru sprawiedliwości, przygotowanie do przesłuchania, nie jest obligatoryjnie zarządzane przez każdym przesłuchaniem w trybie art. 185a KPK. Nie umniejsza to jednak znaczenia tej czynności. Powodem, dla którego przygotowuje się małoletniego do udziału w przesłuchaniu jest fakt, iż bardzo często dzieciom przed przesłuchaniem towarzyszy paraliżujący je strach $^{25}$. Dzieci nie wiedzą, dlaczego obcy dla nich ludzie zadają im pytania, dotyczące traumatycznych przeżyć jakich doświadczyły. Jak wskazuje się w literaturze, dziecko powinno wiedzieć, czego się od niego oczekuje, co się wydarzy i czego może się domagać od organów procesowych ${ }^{26}$. Małoletniego do przesłuchania przygotowuje biegły psycholog. Jego zadaniem w ramach tej czynności jest wyjaśnienie dziecku procedur prawnych (w tym jak przebiega przesłuchanie i gdzie się ono odbywa), pouczenie o prawach i obowiązkach, w sposób adekwatny do stopnia rozwoju dziecka, a także pokazanie dziecku pokoju przesłuchań. Do prawidłowego i efektywnego przygotowania dziecka do przesłuchania konieczna jest znajomość psychiki dziecka, dlatego to zadanie powierza się biegłemu psychologowi, a nie sędziemu czy prokuratorowi. Należy w tym miejscu również podkreślić, że nie wolno rozumieć przygotowania małoletniego do przesłuchania jako wyuczenie dziecka scenariusza przesłuchania oraz informacji, które małoletni ma przekazać podczas czynności oraz jak ma się zachowywać. Dzięki możliwości przygotowania dziecka do udziału w przesłuchaniu daje się mu poczucie bezpieczeństwa i minimalizuje ryzyko negatywnych konsekwencji psychicznych jakie mogą wystąpić u dziecka na skutek przesłuchania ${ }^{27}$.

\footnotetext{
23 A. Gadomska, op. cit., s. 192; M. Horna, op. cit., s. 24-25.

${ }^{24}$ J. Zmarzlik, op. cit., s.78.

25 A. Budzyńska, O. Trocha, Dziecko uczestniczace w postępowaniu karnym, Warszawa 2015,

${ }^{26}$ Ibidem, s. 19.

27 A. Gadomska, op. cit., s. 194.
} s. 19. 
Niezależnie od tego, czy małoletni został przygotowany, następuje jego przesłuchanie. Jak wyżej zostało wskazane, odbywa się ono na posiedzeniu sądu, w specjalnie do tego przygotowanym pokoju przesłuchań. Przesłuchanie dziecka w trybie art. 185a KPK, składa się z 4 faz. Faza pierwsza, to inaczej etap swobodnej wypowiedzi, podczas którego sędzia przedstawia siebie oraz inne osoby biorące udział w przesłuchaniu. Ponadto powinien powiedzieć czym się zajmuje, poinformować, że ich rozmowa jest nagrywana, zapytać o imię i nazwisko przesłuchiwanego dziecka, do której chodzi klasy, czy ma jakieś pytania, a jeśli tak to na nie odpowiedzieć ${ }^{28}$. Faza druga, to faza swobodnej wypowiedzi, która polega na spontanicznej relacji małoletniego na temat zdarzenia ${ }^{29}$. Faza trzecia, to faza pytań szczegółowych. Sędzia zadaje wówczas dziecku pytania, w celu uporządkowania tego co dziecko zeznało, a także uzyskania innych dodatkowych informacji ${ }^{30}$. Ostatnia faza to czynności końcowe, które zmierzają do tego, aby dziecko odreagowało składanie zeznań, np. poprzez krótką rozmowę o zainteresowaniach dziecka. Następnie sędzia dziękuje dziecku za przybycie i poświęcenie czasu ${ }^{31}$. Jak wynika z powyższego, małoletni jest głównie przesłuchiwany przez sędziego, ale w przesłuchaniu bierze udział również biegły psycholog. Należy w tym miejscu podkreślić, że rola biegłego nie sprowadza się w tym wypadku jedynie do biernej obecności, lecz do aktywnego uczestniczenia w tej czynności procesowej. Jego rola polega na pomaganiu sędziemu w formułowaniu pytań do małoletniego oraz wytłumaczeniu w zrozumiały sposób czego dotyczy pytanie. Wyjątkowo może się zdarzyć, że na wniosek sędziego to właśnie biegły może być osobą wiodącą w przesłuchaniu, a nawet przesłuchać dziecko, jeżeli np. sędzia nie jest w stanie zapanować nad małoletnim ${ }^{32}$.

Po zakończonym przesłuchaniu biegły ma obowiązek przedstawić sądowi ustnie lub pisemnie opinię $\mathrm{w}$ zakreślonym przez sąd wymiarze wraz $\mathrm{z}$ odpowiedziami na zadane przez sąd pytania wraz z krótkim uzasadnieniem. W swojej opinii biegły psycholog powinien odnieść się do osobowości świadka, stopnia rozwoju umysłowego oraz posiadanej przez małoletniego zdolności postrzegania. Opinia nie zawiera treści zeznań złożonych przez małoletniego, lecz odnosi się do skutków $\mathrm{w}$ wymiarze psychicznym wynikające $\mathrm{z}$ doświadczenia go przestępstwem oraz ewentualnie wynikające z nich przeciwwskazania dla ponownego składania zeznań przez dziecko ${ }^{33}$. Ponadto biegły powinien zaprezentować osobowość świadka.

28 "Jak prowadzić przesłuchanie dziecka. Metodyka przesłuchania małoletniego świadka"- dostępne na: http://wymiarsprawiedliwosci.fdn.pl.

29 A. Gadomska-Radel, op. cit., s. 215-216.

${ }^{30}$ M. Kornak, op. cit., s. 191.

31 A. Wesołowska, op. cit., s. 3-4.

${ }_{32}$ M. Horna, op. cit., s. 24-25.

33 A. Gadomska - Radel, Ocena wiarygodności zeznań dzieci, «Prokuratura i Prawo», 2010, nr 11, s. 79. 
Należy podkreślić, że biegły może prowadzić badania pod kątem ustalenia psychologicznych kryteriów wiarygodności odpowiedzi udzielonych przez małoletniego. Biegły powinien w opinii wyjaśnić również wszystkie wynikłe w trakcie przesłuchania kwestie, których rozstrzygnięcie przekracza kompetencje procesowe sądu. Sądowi nie wolno, natomiast wymagać od biegłego oceny wiarygodności złożonych przez małoletniego zeznań oraz żądać odpowiedzi na pytanie: czy małoletni mówi prawdę? czy zeznania małoletniego można uznać za wiarygodne? Biegły nie może badać w swojej opinii ani treści ani formy zeznań świadka, pod względem ich szczerości i formułować ocen co do ich wiarygodności ${ }^{34}$. Zawieranie $w$ treści opinii odpowiedzi na te pytania byłoby próbą oceny dowodów przez biegłego, a co należy do wyłącznej kompetencji sądu w procesie karnym, co wynika wprost z art. 7 KPK. Jak trafnie wskazuje E. Gruza sąd powinien wystrzegać się tzw. "fetyszyzacji" i bezkrytycznego przyjmowania ustaleń, gdyż w przeciwnym razie świadczyłoby to o niezrozumieniu istoty dowodu z opinii biegłego $0^{35}$.

Podsumowując powyższe rozważania, należy stwierdzić iż przesłuchanie w trybie art. 185a KPK pokrzywdzonego małoletniego jest formą jego ochrony przed wtórną wiktymizacją. Katalog osób, które są obecne podczas tej czynności jest zamknięty, ponieważ większa liczba osób mogłaby spowodować zakłócenie koncentracji uwagi oraz ograniczać zaufanie i gotowość do współdziałania przez dziecko. W przesłuchaniu małoletniego bierze udział sąd oraz biegły psycholog. Biegły nie jest w tej czynności biernym obserwatorem, lecz jej aktywnym uczestnikiem. Jest on powoływany przez sąd i jego rola polega na przygotowaniu małoletniego do udziału w przesłuchaniu, pomoc sędziemu podczas przesłuchania oraz sporządzenie opinii. Należy wobec tego stwierdzić, że biegły psycholog jest zarówno pomocnikiem jak i konsultantem sądu. Jego udział w przesłuchaniu małoletniego ma ogromne znaczenie z kilku powodów. Po pierwsze, daje on poczucie bezpieczeństwa dziecku, gdyż potrafi rozmawiać z nim w sposób zrozumiały i adekwatny dla jego wieku. Dziecko jest zestresowane całą sytuacją, w której się znajduje, a brak zrozumienia tego co mówią do niego obcy ludzie podczas przesłuchania jeszcze ten strach potęguje. Po drugie, biegły psycholog pomaga sędziemu dotrzeć do dziecka i porozumieć się z nim, co może wpłynąć na jakość jego zeznań. Nie każdy sędzia potrafi postępować z dziećmi, wobec tego potrzebna mu jest osoba, która wspomoże go podczas tej czynności. Ogromnie ważna jest jakość zeznań uzyskanych od małoletniego pokrzywdzonego, gdyż można go przesłuchać w tej samej sprawie, co do zasady, tylko jeden raz. Po trzecie, biegły sporządzając opinię, pomaga sądowi zrozumieć stan psychiczny przesłuchanego dziecka, co może wpłynąc na dokonywaną przez sąd ocenę dowodów, gdy będzie wydawał wyrok

${ }^{34}$ J. Mierzwińska-Lorencka, Karnoprawna ochrona dziecka przed wykorzystywaniem seksualnym, dostęp el/LEX, dostęp na dzień: 25 stycznia 2019r.

35 E. Gruza, Psychologia sq̨dowa dla prawników, Warszawa 2012, s. 279-280. 
w sprawie. Jednakże, należy pamiętać, że sąd, który powołuje biegłego do udziału w przesłuchaniu, nie powinien oczekiwać od niego informacji, czy dziecko podczas przesłuchania mówiło prawdę oraz czy jego zeznania można uznać za wiarygodne, a także, sąd nie powinien dokonywać bezkrytycznego przyjmowania ustaleń biegłego psychologa.

\section{BIBLIOGRAFIA}

Brojek M., Uwagi i postulaty dotyczące taktyki przestuchania w charakterze świadka osoby nieletniej, «Prokuratura i Prawo», 1998, nr 1.

Budzyńska A., Diagnoza psychologiczna wykorzystywania seksualnego dzieci [w:] Sajkowska M. (red.), Dziecko wykorzystywane seksualnie. Diagnoza, interwencja, pomoc psychologiczna, FDN, Warszawa 2010.

Budzyńska A., O. Trocha, Dziecko uczestniczace w postępowaniu karnym, Warszawa 2015.

Gadomska A., Przygotowanie do przestuchania małoletniej ofiary w charakterze świadka, «Prokuratura i Prawo», 2008, nr 7-8.

Gadomska-Radel A., Ocena wiarygodności zeznań dzieci, «Prokuratura i Prawo», 2010, nr 11.

Gadomska-Radel A., Przestuchanie dziecka jako ofiary przestęstwa, Warszawa 2015.

Gruza E., Psychologia sądowa dla prawników, Warszawa 2012.

Horna M., Nowelizacja kodeksu postępowania karnego a ochrona małoletniego podczas przestuchania, «Dziecko krzywdzone. Teoria, badania, praktyka», vol. 13 Nr 2 (2014).

Kornak M., Małoletni jako świadek w procesie karnym, Warszawa 2009.

Kosior R., Wybrane zagadnienia w zakresie przestuchiwania małoletniego świadka na tle art. 185 a i $185 b$ kpk, «Dziecko krzywdzone. Teorie, badania, praktyka», 2010, nr 1.

Leśniak M., Wybrane problemy badań psychologicznych w procesie karnym, «Prokuratura i Prawo», 1998 , nr 5.

Mierzwińska-Lorencka J., Karnoprawna ochrona dziecka przed wykorzystywaniem seksualnym, dostęp el/LEX, dostęp na dzień: 25 stycznia 2019r.

Osiak K., Kryminalistyczno-procesowe aspekty przestuchania w trybie art. 185 a k.p.k., «Prokuratura i Prawo», 2018, $\mathrm{nr} 6$.

Stefański R.A., Przestuchanie pokrzywdzonego poniżej lat 15 w procesie karnym [w:] Współczesne problemy procesu karnego i jego efektywności. Księga pamiątkowa profesora Andrzeja Bulsiewicza, red. A. MAREK, Toruń 2004.

Wesołowska A., Dziecko w procesie sądowym - podejście interdyscyplinarne, «Dziecko krzywdzone. Teoria, badania, praktyka», vol. $4 \mathrm{nr} 1$.

Zmarzlik J., Przygotowanie dziecka do uczestnictwa w przestuchaniu [w:] Sajkowska M. (red.), Przyjazne przestuchanie dziecka, FDN, Warszawa 2007.

\section{SUMMARY}

About 6 million children live in Poland. Unfortunately, according to statistics, about 10,000 minors are killed each year. These are only estimates because we will never know how many children actually become victims of crime, because very often the fact of committing a crime is not reported to the police or the prosecutor's office. If criminal proceedings are instituted against the perpetrator 
Pobrane z czasopisma Studenckie Zeszyty Naukowe http://szn.umcs.pl Data: 26/04/2023 12:29:47

Rola biegłego psychologa w przesłuchaniu dziecka w trybie art. 185a...

of abuse of a minor, then his / her participation in the trial and thus his / her hearing as a witness may be necessary. In art. 185a of the Code of Criminal Procedure, a special procedure of interrogation of a minor victim has been regulated to protect him against secondary victimization. The hearing takes place at a court meeting in which a proficient psychologist also participates. The aim of the article is to present the role of a proficient psychologist in interrogating a minor victim.

Key words: interrogation, expert, psychologist, minor, child 